\title{
Occurrence of the northern root-knot nematode Meloidogyne hapla Chitwood, 1949 (Nematoda: Meloidogynidae) in seed potatoes on the territory of Poland
}

\author{
Wystąpienie guzaka północnego Meloidogyne hapla Chitwood, 1949 \\ (Nematoda: Meloidogynidae) w sadzeniakach na terytorium Polski
}

Witold Karnkowski ${ }^{1}$, Renata Dobosz ${ }^{2}$, Małgorzata Stadnicka ${ }^{3}$, Marta Saldat ${ }^{1}$

\begin{abstract}
Summary
During official controls of seed potatoes performed by the State Plant Health and Seed Inspection Service in 2011-2012, the presence of the northern root-knot nematode (Meloidogyne hapla Chitwood, 1949) was revealed in 21 tuber samples originating from the area of Lubelskie Voivodeship in Poland. In 2011 the level of infestation was 2.61\% (11 from among 422 tested samples were infested) and in $2012-2.81 \%$ (the nematodes were found in 10 samples from among 356 tested). The results of the morphological and morphometric analyses of females and $\mathrm{J} 2$ juveniles isolated from all 21 positive samples were confirmed by results of conducted molecular tests (PCR-ITS - Polymerase Chain Reaction-Internal Transcribed Spacer, PCR-SCAR - Polymerase Chain Reaction-Sequence Characterized Amplified Regions and PCR-RFLP - Polymerase Chain Reaction-Restriction Fragment Length Polymorphism) which simultaneously excluded presence of quarantine root-knot nematode species Meloidogyne chitwoodi (Golden et al. 1980) and M. fallax (Karssen 1996).
\end{abstract}

Key words: Meloidogyne hapla, northern root-knot nematode, Poland, seed potatoes

\begin{abstract}
Streszczenie
Podczas urzędowych kontroli sadzeniaków ziemniaka prowadzonych przez Państwową Inspekcję Ochrony Roślin i Nasiennictwa w latach 2011-2012 stwierdzono obecność guzaka północnego (Meloidogyne hapla Chitwood, 1949) w 21 próbach bulw pochodzących z terenu województwa lubelskiego. W roku 2011 stopień porażenia wynosił 2,61\% (porażonych było 11 spośród 422 badanych prób), natomiast w 2012 r. - 2,81\% (nicienie stwierdzono w 10 próbach spośród 356 badanych). Wyniki analiz morfologicznych i morfometrycznych samic i osobników młodocianych J2 nicieni wyizolowanych ze wszystkich 21 prób pozytywnych zostały potwierdzone przez wyniki przeprowadzonych testów molekularnych (PCR-ITS - Polymerase Chain Reaction-Internal Transcribed Spacer, PCR-SCAR Polymerase Chain Reaction-Sequence Characterized Amplified Regions and PCR-RFLP - Polymerase Chain Reaction-Restriction Fragment Length Polymorphism), które jednocześnie wykluczyły przynależność nicieni do kwarantannowych gatunków Meloidogyne chitwoodi (Golden i wsp. 1980) i M. fallax (Karssen 1996).
\end{abstract}

Słowa kluczowe: Meloidogyne hapla, guzak północny, Polska, sadzeniaki ziemniaka

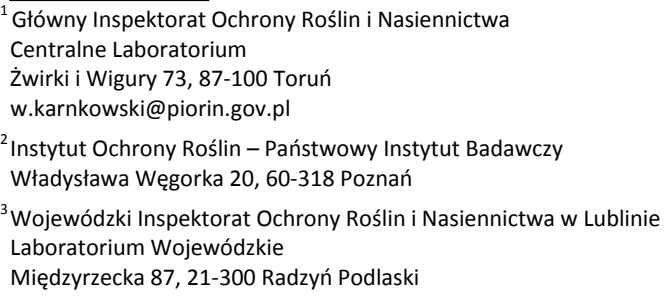




\section{Wstęp / Introduction}

Guzak północny, Meloidogyne hapla Chitwood, 1949 jest polifagicznym gatunkiem nicienia pasożytującym na ponad 500 gatunkach roślin dwuliściennych. Wyrośla powstające na korzeniach porażonych przez ten gatunek sporadycznie obserwowano także na roślinach jednoliściennych z rodzaju Allium i Hosta (Karssen 1999). W wielu krajach świata $M$. hapla jest szkodnikiem ziemniaka porażającym zarówno korzenie roślin, jak i bulwy. W Polsce po raz pierwszy guzaka północnego znaleziono w uprawie ziemniaka, w latach 50. XX wieku (Wilski 1971), lecz przedstawione wyniki opisują jedynie obraz porażenia korzeni roślin. Brakuje informacji czy nicień ten był obserwowany także na bulwach.

W trakcie badań sadzeniaków ziemniaka przeprowadzonych przez Państwową Inspekcję Ochrony Roślin i Nasiennictwa (PIORiN) w ramach urzędowych kontroli zdrowotności stwierdzono, że część badanych bulw była porażona przez M. hapla. W artykule opisano i zilustrowano procedurę identyfikacji nicieni, które porażały bulwy - analizę objawów porażenia, analizę cech morfologicznych samic i osobników młodocianych J2 oraz wyniki testów molekularnych.

\section{Materiały i metody / Materials and methods}

Badania sadzeniaków ziemniaka pod kątem obecności guzaków (Meloidogyne spp.) przeprowadzono w latach 2011 i 2012 (przebadano odpowiednio 422 i 356 prób po 200 bulw każda) w Wojewódzkim Inspektoracie Ochrony Roślin i Nasiennictwa w Lublinie (Laboratorium Wojewódzkie w Radzyniu Podlaskim). Bulwy obserwowano makroskopowo w celu zlokalizowania zewnętrznych objawów porażenia - niewielkich płaskich wyrośli na powierzchni zwykle o średnicy nieprzekraczającej $1 \mathrm{~cm}$. Następnie poszukiwano objawów porażenia wewnętrznego - z bulw zdejmowano skórkę w poszukiwaniu brązowych, nekrotycznych plamek o średnicy $0,5-1,0 \mathrm{~mm}$. W celu pozyskania wystarczającej liczby osobników niezbędnych do identyfikacji, fragmenty powierzchniowej części porażonych bulw ziemniaka obejmujące skórkę i warstwę miąższu o grubości 1-2 mm, poddano analizie z zastosowaniem metody enzymatycznej (OEPP/EPPO 2009; Laboratoire national de la protection des végétaux 2009) w Centralnym Laboratorium Głównego Inspektoratu Ochrony Roślin i Nasiennictwa. Pobrany materiał roślinny umieszczono w pojemnikach o pojemności $200 \mathrm{ml}$, zalano mieszaniną celulazy (preparat enzymatyczny Celluclast $1,5 \mathrm{~L}$ ) i pektynazy (preparat enzymatyczny Pectinex Ultra SP-L) oraz przykrywano wieczkami. Tak przygotowane próby poddano wytrząsaniu przez 24 godziny (100-150 cykli na minutę). Po tym czasie zawartość pojemników cedzono przez zestaw sit o średnicy oczek: 0,6, 0,16 i 0,02 mm. Materiał pozostały na górnym sicie usuwano, natomiast materiał zebrany na sitach o średnicy oczek 0,16 i $0,02 \mathrm{~mm}$ umieszczano małymi partiami na szalkach Petriego i analizowano pod kątem obecności samic oraz osobników młodocianych guzaków.
Identyfikację samic i osobników młodocianych J2 metodą mikroskopową (morfologiczno-metryczną) przeprowadzono w oparciu o publikacje Brzeskiego (1998), Karssena (1999) oraz Dobosz i wsp. (2008). Następnie materiał poddano badaniom $\mathrm{z}$ zastosowaniem technik biologii molekularnej. Wykonano test PCR-ITS (Polymerase Chain Reaction-Internal Transcribed Spacer), którego wynik miał potwierdzić lub wykluczyć przynależność badanych nicieni do rodzaju Meloidogyne. Wykonanie kolejnego testu PCR-SCAR (Polymerase Chain ReactionSequence Characterized Amplified Regions) pozwoliło ocenić, czy nicienie należą do gatunków kwarantannowych M. chitwoodi i $M$. fallax, natomiast test PCR-RFLP (Polymerase Chain Reaction-Restriction Fragment Length Polymorphism) umożliwił ich identyfikację do gatunku M. hapla (OEPP/EPPO 2009). W przypadku, gdy w materiale wykryto tylko nieliczne samice lub same złoża jajowe identyfikację przeprowadzano wyłącznie z zastosowaniem testów molekularnych.

\section{Wyniki i dyskusja / Results and discussion}

Spośród 422 prób sadzeniaków ziemniaka przebadanych w 2011 roku 11 prób (2,6\%) było porażonych przez $M$. hapla. W badanych bulwach stwierdzono obecność zarówno samic, jak i osobników młodocianych oraz złóż jajowych tego nicienia. Spośród 356 prób sadzeiaków poddanych analizie w roku 2012, obecność guzaka północnego odnotowano w 10 próbach $(2,8 \%)$, z których wyizolowano wszystkie wymienione wyżej stadia rozwojowe nicieni.

Obserwowane bulwy nie wykazywały żadnych objawów porażenia zewnętrznego. Dopiero pod skórką bulw, na głębokości do $0,5 \mathrm{~cm}$, często w okolicach oczek,

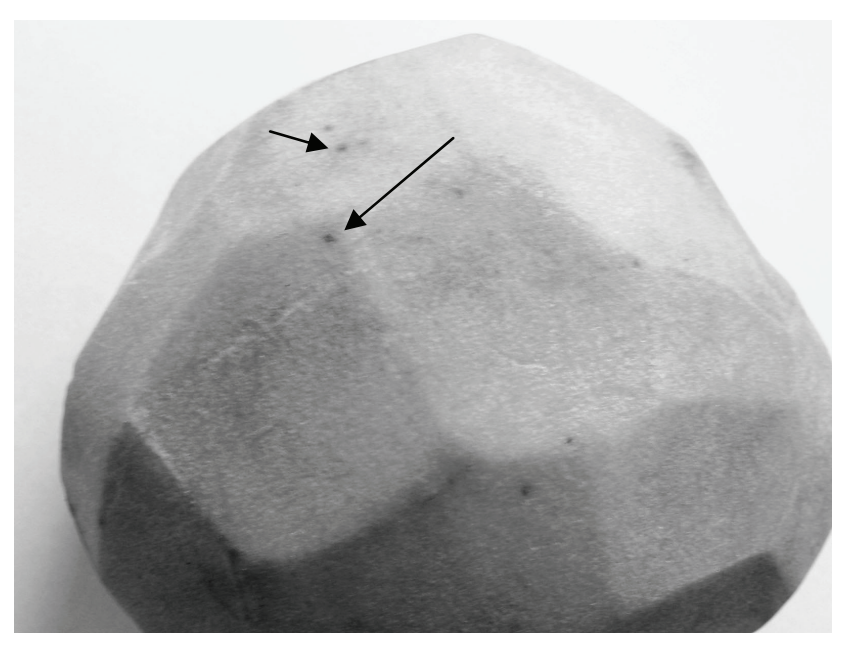

Rys. 1. Bulwa ziemniaka porażona przez M. hapla - widoczne wewnętrzne objawy porażenia w postaci niedużej liczby brunatnych plamek w miąższu, w miejscu występowania samic (fot. Tomasz Konefał)

Fig. 1. Potato tuber infested with M. hapla - internal symptoms in the form of small number of brown dots in the place of occurrence of females (phot. Tomasz Konefał) 


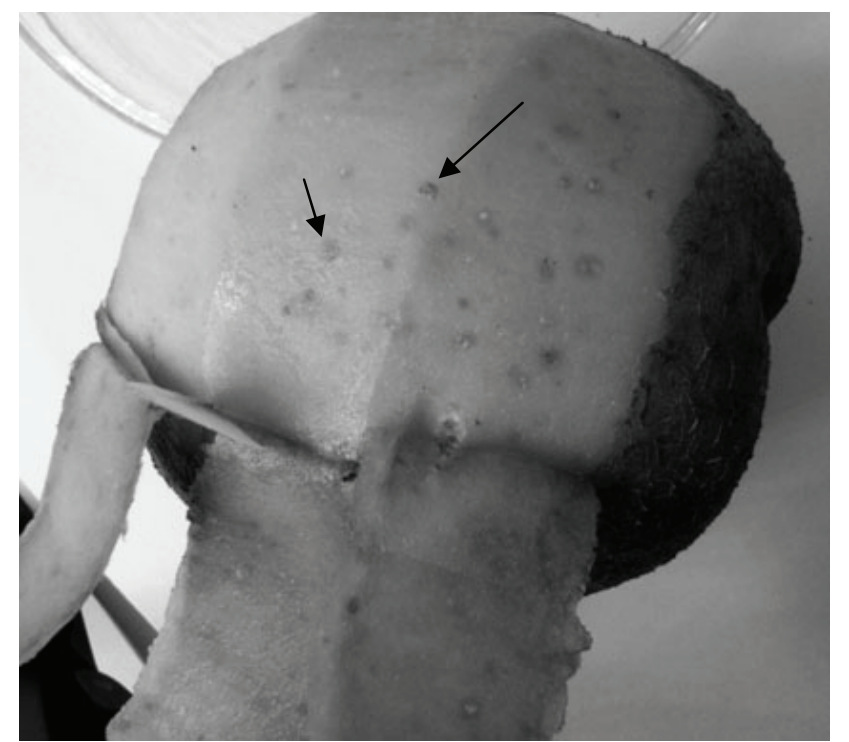

Rys. 2. Bulwa ziemniaka porażona przez M. hapla - widoczne wewnętrzne objawy porażenia w postaci znacznej liczby brunatnych plamek w miąższu, w miejscu występowania samic (fot. Małgorzata Stadnicka)

Fig. 2. Potato tuber infested with M. hapla - internal symptoms in the form of significant number of brown dots in the place of occurrence of females (phot. Małgorzata Stadnicka)

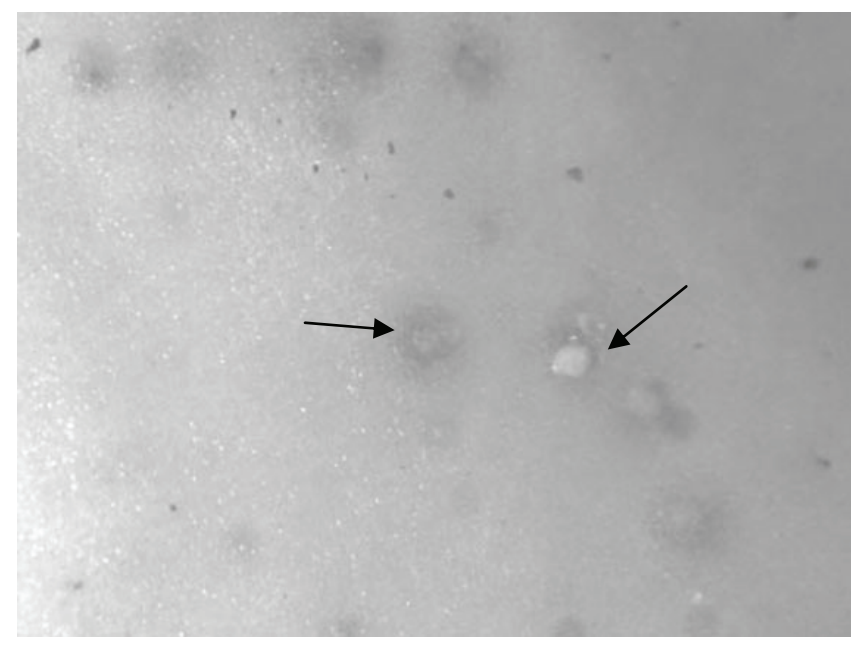

Rys. 3. Samice M. hapla i brunatne plamki spowodowane ich żerowaniem w miąższu bulwy ziemniaka (fot. Małgorzata Stadnicka)

Fig. 3. M. hapla females and brown dots caused by nematode feeding in potato tuber flash (phot. Małgorzata Stadnicka)

obserwowano obecność małych, około $1 \mathrm{~mm}$ średnicy, nekrotycznych, brązowych plamek w miejscach występowania samic guzaka. Plamki te występowały najczęściej w niewielkiej liczbie (rys. 1), większe nasilenie ich występowania odnotowano jedynie w pojedynczych bulwach (rys. 2, 3).

Cechy morfologiczne płytek perinealnych samic (przede wszystkim punktowanie oskórka samicy w okolicy odbytu u części osobników) (rys. 4) oraz charakterystyczny nieregularny kształt przezroczystej części ogona osobników młodocianych $\mathrm{J}_{2}$ (rys. 5) wskazywały na przynależność nicieni do gatunku $M$. hapla.

Przeprowadzony test molekularny PCR-ITS potwierdził, że nicienie wyizolowane ze wszystkich 21 próbek należały do rodzaju Meloidogyne (rys. 6). Wyniki kolejnego testu (PCR-SCAR) pozwoliły stwierdzić, że nicienie te nie należą do gatunków kwarantannowych guzaka amerykańskiego (M. chitwoodi) i guzaka holenderskiego (M. fallax) (rys. 6). Wyniki następnego testu (PCR-RFLP) wykazały jednoznacznie, że we wszystkich badanych próbach znajdują się nicienie z gatunku $M$. hapla (rys. 7-8).

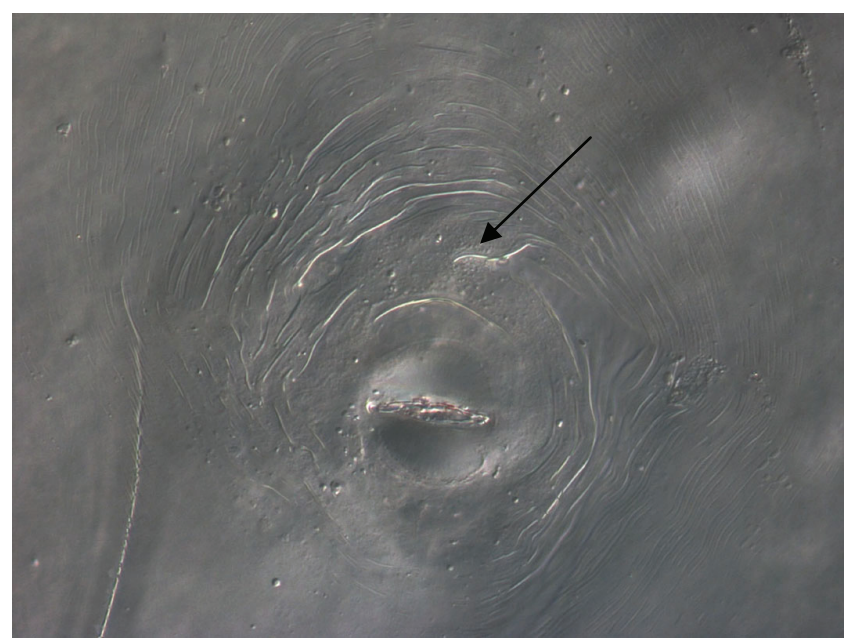

Rys. 4. Płytka perinealna samicy M. hapla z punktowaniem oskórka w okolicy odbytu (fot. Renata Dobosz)

Fig. 4. Perineal pattern of M. hapla female with cuticular punctations in tail terminus area (phot. Renata Dobosz)

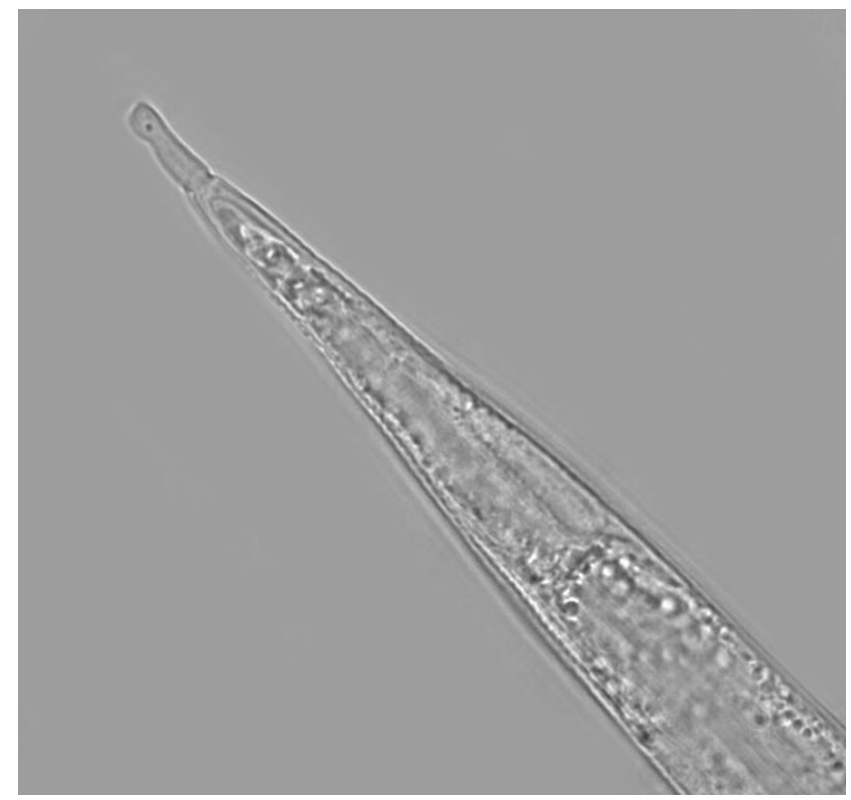

Rys. 5. Ogon osobnika młodocianego $\left(\mathrm{J}_{2}\right)$ M. hapla $\mathrm{z}$ charakterystycznie nieregularną częścią hyalinową (fot. Witold Karnkowski)

Fig. 5. M. hapla juvenile $\left(\mathrm{J}_{2}\right)$ with characteristically irregular hyaline part (phot. Witold Karnkowski) 


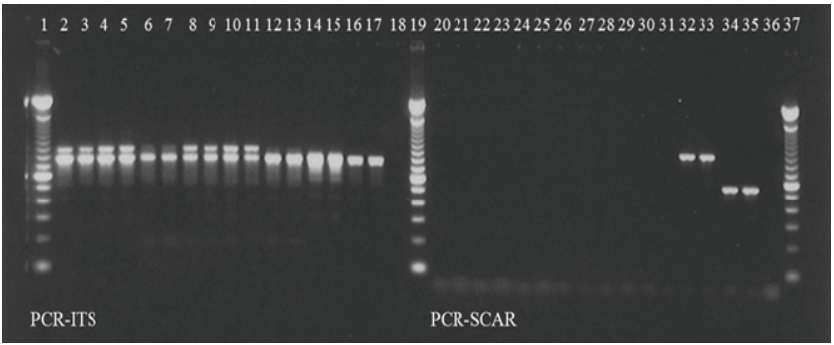

Rys. 6. Rozkład elektroforetyczny produktów reakcji PCR-ITS i PCR-SCAR: 1, 19, 37 - marker DNA (100 bp DNA Ladder, Invitrogen); 2-11 - badane próbki; 12, 13 kontrola pozytywna $M$. hapla; 14,15 - kontrola pozytywna M. chitwoodi; 16, 17 - kontrola pozytywna M. fallax; 18 - kontrola negatywna PCR. Oczekiwany produkt reakcji PCR-ITS dla Meloidogyne spp. 760 pz. 21-29 - badane próbki; 30, 31 - kontrola pozytywna M. hapla; 32, 33 - kontrola pozytywna M. chitwoodi; 34, 35 - kontrola pozytywna M. fallax; 36 - kontrola negatywna PCR. Oczekiwany produkt reakcji PCRSCAR dla $M$. chitwoodi wynosi $\sim 800 \mathrm{pz}$, dla M. fallax $\sim 515 \mathrm{pz}$, dla M. hapla brak produktu (fot. Marta Saldat)

Fig. 6. PCR-ITS and PCR-SCAR products profiles: 1, 19, 37 DNA marker (100 bp DNA Ladder, Invitrogen); 2-11 samples tested; 12,13 - positive control for M. hapla; 14 , 15 - positive control for $M$. chitwoodi; 16,17 - positive control for M. fallax; 18 - negative PCR control. Expected amplicon size of PCR-ITS for Meloidogyne spp. is $\sim 760$ pz. 21-29 - samples tested; 30,31 - positive control for $M$. hapla; 32,33 - positive control for M. chitwoodi; 34, 35 - positive control for M. fallax; 36 negative PCR control. Expected amplicon size of PCRSCAR for $M$. chitwoodi is $\sim 800 \mathrm{bp}$, for $M$. fallax $\sim 515 \mathrm{bp}$, for $M$. hapla no amplification product (phot. Marta Saldat)

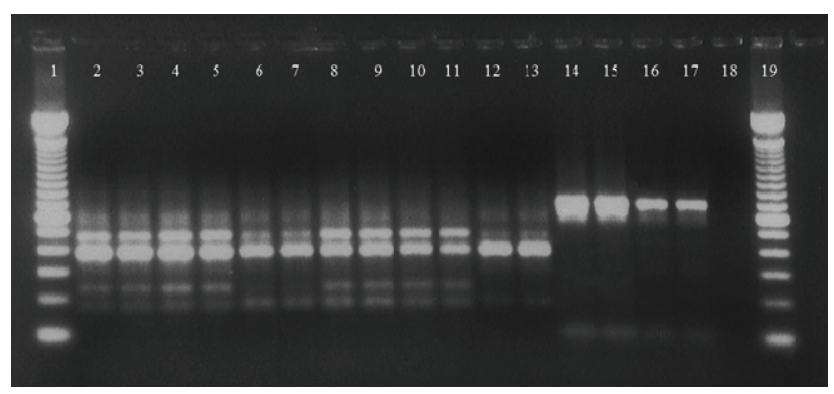

Rys. 7. Rozkład elektroforetyczny produktów reakcji RFLP, trawionych DraI. 1, 19 - marker DNA (100 bp DNA Ladder, Invitrogen); 2-11 - badane próbki; 12, 13 kontrola pozytywna $M$. hapla; 14, 15 - kontrola pozytywna $M$. chitwoodi; 16, 17 - kontrola pozytywna M. fallax; 18 - kontrola negatywna PCR. Oczekiwany produkt reakcji RFLP z enzymem DraI wynosi $\sim 360,380$ pz dla $M$. hapla , $\sim 660,100$ pz dla M. chitwoodi i $\sim 650$, $110 \mathrm{pz}$, dla M. fallax (fot. Marta Saldat)

Fig. 7. Pattern of RFLP products, digested with DraI. 1, $19-$ DNA marker (100 bp DNA Ladder, Invitrogen); 2-11 samples tested; 12,13 - positive control for M. hapla; 14 , 15 - positive control for M. chitwoodi; 16, 17 - positive control for M. fallax; 18 - negative PCR control. Expected size of amplified RFLP products with enzyme DraI is $\sim 360,380 \mathrm{bp}$ for M. hapla , $660,100 \mathrm{bp}$ for M. chitwoodi and $\sim 650,110$ bp for M. fallax (phot. Marta Saldat)

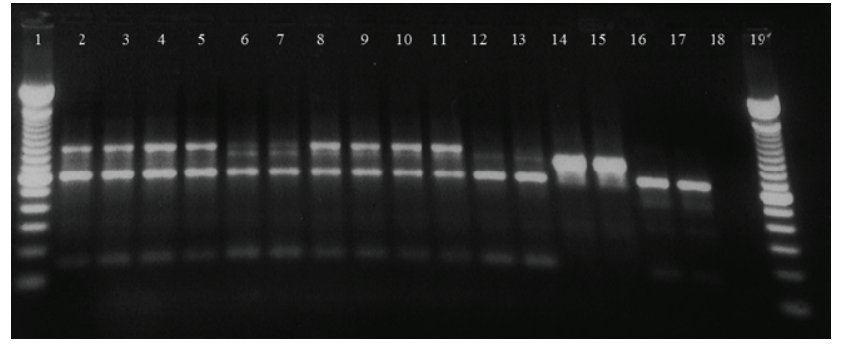

Rys. 8. Rozkład elektroforetyczny produktów reakcji RFLP, trawionych RsaI. 1, 19 - marker DNA (100 bp DNA Ladder, Invitrogen); 2-11 - badane próbki; 12, 13 kontrola pozytywna $M$. hapla; 14,15 - kontrola pozytywna M. chitwoodi; 16, 17 - kontrola pozytywna M. fallax; 18 - kontrola negatywna PCR. Oczekiwany produkt reakcji RFLP z enzymem $R s a$ I wynosi $\sim 620,140$ pz dla M. hapla, $\sim 760 \mathrm{pz}$ dla M. chitwoodi i $\sim 630,130 \mathrm{pz}$ dla M. fallax (fot. Marta Saldat)

Fig. 8. Pattern of RFLP products, digested with RsaI. 1, $19-$ DNA marker (100 bp DNA Ladder, Invitrogen); 2-11 samples tested; 12,13 - positive control for M. hapla; 14 , 15 - positive control for M. chitwoodi; 16,17 - positive control for M. fallax; 18 - negative PCR control. Expected size of amplified RFLP products with enzyme RsaI is $\sim 620,140$ bp for M. hapla, 760 bp for M. chitwoodi and $\sim 630,130$ bp for M. fallax (phot. Marta Saldat)

W trakcie urzędowej kontroli zdrowotności sadzeniaków ziemniaka przeprowadzonej w latach 2011-2012 stwierdzono występowanie $M$. hapla jedynie w bulwach ziemniaka pochodzących $\mathrm{z}$ obszaru województwa lubelskiego. Nie stwierdzono natomiast obecności nicieni z rodzaju Meloidogyne w sadzeniakach pochodzących z terenu pozostałych województw (niepublikowane dane Państwowej Inspekcji Ochrony Roślin i Nasiennictwa). Wyniki analiz wykazały, że procent porażenia bulw był stosunkowo niski i nie przekroczył 3\%. W badaniach przeprowadzonych w stanie Waszyngton (USA) w latach 1980-1981, wykazano wystąpienie guzaka północnego łącznie aż w 41\% prób bulw ziemniaka oraz gleby pochodzącej z upraw tej rośliny (MacGuidwin i Rouse 1990). Wyniki badań przeprowadzonych w latach 2011-2012 na obszarze Bośni i Hercegowiny wskazały występowanie M. hapla we wszystkich badanych próbkach pochodzących z obszaru Nevesinje oraz w próbkach pobranych z 12 spośród 20 pól ziemniaczanych na obszarze Rogatica (Nježić i wsp. 2012). Oprócz obserwowanych objawów porażenia wewnętrznego bulw, autorzy obserwowali także objawy ich porażenia zewnętrznego w postaci niewielkich, guzowatych wyrośli (Nježić, informacja osobista), które nie wystąpiły na zewnętrznych tkankach bulw pochodzących z województwa lubelskiego. Należy przypuszczać, że zagęszczenie osobników $\mathrm{w}$ glebie $\mathrm{z}$ pól pochodzących z województwa lubelskiego było zbyt niskie, aby możliwe było wykształcenie się zewnętrznych objawów porażenia. Olthof i Potter (1972) obserwowali takie objawy na bulwach uprawianych na polach, na których liczebność osobników młodocianych J2 wynosiła od 6 do 18 tysięcy sztuk w kilogramie gleby. Nie można również wykluczyć, że na zaobserwowane wyniki wpłynęły również czynniki, takie jak wyższy stopień patogeniczności populacji guzaka czy 
też wrażliwość odmiany ziemniaka oraz łagodne warunki klimatyczne na terenie Bośni i Hercegowiny. Brak wystąpienia zewnętrznych objawów porażenia bulw ziemniaka utrudnia prawidłową ocenę porażenia zarówno sadzeniaków, jak i bulw konsumpcyjnych i przemysłowych.

\section{Wnioski / Conclusions}

Wyniki badań dowodzą, że na terytorium Rzeczypospolitej Polskiej guzak północny (M. hapla) poraża bulwy ziemniaka. Brak charakterystycznych zewnętrznych objawów porażenia bulw utrudnia wykrywanie tego nicienia w badanym materiale. Konieczne jest zatem kontynuowanie badań dotyczących występowania guzaków zarówno w sadzeniakach oraz ziemniakach konsumpcyjnych i przemysłowych, aby móc ocenić stopień nasilenia występowania M. hapla w uprawach ziemniaka.

\section{Literatura / References}

Brzeski M.W. 1998. Nematodes of Tylenchina in Poland and Temperate Europe. Muzeum i Instytut Zoologii PAN, Warszawa, 398 pp.

Dobosz R., Obrępalska-Stęplowska A., Nowaczyk K., Kornobis S. 2008. Diagnostyka nicieni pasożytów objętych regulacjami prawnymi. Instrukcja do rozpoznawania gatunków z rodzaju Meloidogyne. Inst. Ochr. Roślin - PIB, Poznań, 13 ss.

Karssen G. 1999. The Plant-Parasitic Nematode Genus Meloidogyne Göldi, 1892 (Tylenchida) in Europe. University of Gent, 160 pp.

Laboratoire national de la protection des végétaux 2009. Préparation d'un mélange enzymatique pour extraction de nématodes endoparasites. Mode operatoire MO0620, 2 pp. (dokument niepublikowany).

MacGuidwin A.E., Rouse D.I. 1990. Effect of Meloidogyne hapla, alone and in combination with subthreshold populations of Verticilium dahliae, on disease symptomology and yield of potato. Phytopathology 80: 482-486.

Nježić B., Mitrović B., Macanović I., Grujić N., Waeyenberge L. 2012. Occurence of northerrn root-knot nematode in Republic of Srpska, Bosnia and Herzegovina, p. 199. In: Proc. 31st International Symposium of the European Society of Nematologists. Turkey, Adana, September 23-27, 2012, 355 pp.

OEPP/EPPO 2009. EPPO Standard. PM 7/41(1) Meloidogyne chitwoodi and M. fallax. Bull OEPP/EPPO Bull. 39: 5-17.

Olthof T.H.A., Potter J.W. 1972. Relationship between population densities of Meloidogyne hapla and crop losses in summer-maturing vegetables in Ontario. Phytopathology 62: 981-986.

Wilski A. 1971. Doświadczenia wazonowe nad wpływem porażenia ziemniaków przez mątwika północnego (Meloidogyne hapla) na plon bulw. Prace Nauk. Inst. Ochr. Roślin 13 (1): 191-194. 